\title{
BLOOD LEVEL STUDIES IN CHICKENS, TURKEY POULTS AND SWINE WITH TIAMULIN, A NEW ANTIBIOTIC
}

\author{
G. LABER and E. Schütze \\ Sandoz Forschungsinstitut GmbH, Brunner Straße 59, A-1235 Vienna, Austria
}

(Received for publication October 3, 1977)

\begin{abstract}
Tiamulin concentrations have been determined in the serum of chickens, turkeys and swine after a single oral administration of various doses. The compound peaked between 2 and 4 hours after drug supply. In the highest dose used $(50 \mathrm{mg} / \mathrm{kg}$ body weight), mean concentrations of $3.5,2.9,4.5 \mu \mathrm{g} / \mathrm{ml}$ for chickens, turkeys and swine, respectively, could be obtained. In poultry, the levels declined between 12 and 24 hours to values not useful for calculation. In swine at 24 hours after administration measurable values could still be detected.
\end{abstract}

Tiamulin is a new derivative of the diterpene antibiotic pleuromutilin. The synthesis and chemical properties of this and other derivatives have been described elsewhere ${ }^{1,2,3)}$. Its evaluation in vitro and in vivo has revealed significant activity against gram-positive bacteria as well as leptospiras, treponemas and mycoplasmas ${ }^{4,5,6)}$. In particular, an impressive chemotherapeutic efficacy has been found in experimental mycoplasma infections in poultry and swine ${ }^{7,8,9)}$ as well as in naturally occurring mycoplasmosis in these animal species under field conditions ${ }^{10,11,12)}$. This paper deals with the results of blood level studies after single oral administration of tiamulin to chickens, turkey poults and swine.

\section{Materials and Methods}

\section{Compound}

Tiamulin ( $81.723 \mathrm{hfu})$, a white crystalline powder, is readily soluble in water and stable in the neutral and acidic solutions. The compound was obtained from Sandoz Ltd., Basle.

\section{Animals and maintenance conditions}

1. Chickens and turkeys: For each dose ten unsexed, seven week old Hubbard chickens, weighing $1.3 \sim 1.7 \mathrm{~kg}$, and ten unsexed, eight week old turkey broilers (Indiko), weighing $1 \sim 1.8 \mathrm{~kg}$ were used. Both animal species were kept in adapted wire cages $(50 \times 50 \mathrm{~cm})$ at a temperature of $24 \pm 1{ }^{\circ} \mathrm{C}$ and a relative humidity of $50 \pm 5 \%$. Feed and water were offered ad libitum.

2. Swine: Five unsexed animals, pure-bred Landschwein, weighing $12 \sim 15 \mathrm{~kg}$, were used per dose. Single animals were kept in metabolism cages $(86 \times 90 \mathrm{~cm})$ at a temperature of $24 \pm 1^{\circ} \mathrm{C}$ and a relative humidity of $50 \pm 5 \%$. The animals were fed $250 \mathrm{~g}$ of a pig starter, twice daily, drinking water was offered by a drinking bowl ad libitum.

\section{Dosage and administration}

Chickens and turkeys were given 25 and $50 \mathrm{mg}$ and swine 10,25 and $50 \mathrm{mg}$ of compound per $\mathrm{kg}$ body weight. Prior to the administration by stomach tube the tiamulin was dissolved in distilled water. Animals were not removed from feed.

Test procedure

Blood samples were taken before and $0.5,1,2,4,8,12$ and 24 hours after application of the compound by puncture of the wing veins, or vena cava cranialis, respectively. The blood samples were allowed to clot at room temperature $\left(22^{\circ} \mathrm{C}\right)$ for $2 \sim 3$ hours. After centrifugation, the serum 
was decanted and kept frozen at $-20^{\circ} \mathrm{C}$ until work up.

The microbiological activity of the serum samples was determined by an agar-well technique using neomycin agar (BBL 10977; pH 7.9 \pm 0.2) and Staph. aureus ATCC 29067 as the test organism.

Statistical evaluation

Arithmetic mean values were calculated using individual measurements. In all cases showing antibiotic concentrations below the detection limit (chickens 0.2 , turkeys $0.2 \sim 0.4$, swine $0.1 \mu \mathrm{g} / \mathrm{ml}$ serum detection limit), 0.5 of this limit was used in the calculations. Statistical calculation was done by analysis of variance by ranks from Kruskal-Wallis, followed where necessary by MANWHITNEY tests ${ }^{13)}$.

\section{Results}

Figs. 1, 2 and 3 show the tiamulin serum levels in chickens, turkeys and swine obtained after a single oral administration of the doses tested.

The calculated mean values of the antibiotic activity in the serum of the three animal species are listed in Tables 1, 2 and 3.

\section{Discussion}

Measurable serum levels of tiamulin could be detected by microbiological assay procedures after single oral administration of different doses in the three animal species. Within the groups of animals (10 birds or 5 pigs, respectively) examined at different times after drug supply, reproducible values were found, indicating that feed did not hinder absorption of the antibiotic.

The maximum levels were reached in the serum of chickens, turkeys and pigs between the 2 nd and 4th hour after application and were found to be proportionate to the dose used. In chickens receiving a single dose of $50 \mathrm{mg} / \mathrm{kg}$ body weight by stomach intubation, antibacterial activity in serum was detected up to 24 hours, whereas birds receiving $25 \mathrm{mg} / \mathrm{kg}$ body weight showed significant measurable values only up to 12 hours after application. Values obtained from this group 24 hours after administration could not be evaluated usefully for calculation.

In turkeys after oral administration of the compound at a dose of $50 \mathrm{mg} / \mathrm{kg}$ body weight serum levels were detected over a period of more than 12 hours. After an application of $25 \mathrm{mg} / \mathrm{kg}$ body

Table 1. Mean arithmetic values and standard deviation of tiamulin activity in serum samples

\begin{tabular}{|c|c|c|c|c|c|c|c|c|c|}
\hline \multirow{2}{*}{\multicolumn{3}{|c|}{ Dose in $\mathrm{mg} / \mathrm{kg}$}} & \multicolumn{7}{|c|}{ Hours after application } \\
\hline & & & 0.5 & 1 & 2 & 4 & 8 & 12 & 24 \\
\hline \multirow{2}{*}{$\begin{array}{l}\text { Chickens } \\
\qquad(10 \text { animals) }\end{array}$} & 25 & $\begin{array}{r}\bar{x} \\
\pm s\end{array}$ & $\begin{array}{l}0.671 \\
0.560\end{array}$ & $\begin{array}{l}1.128 \\
0.683\end{array}$ & $\begin{array}{l}1.680 \\
0.515\end{array}$ & $\begin{array}{l}1.699 \\
0.347\end{array}$ & $\begin{array}{l}0.851 \\
0.42\end{array}$ & $\begin{array}{l}0.166 \\
0.11\end{array}$ & $\begin{array}{l}+) \\
+)\end{array}$ \\
\hline & 50 & $\begin{array}{r}\bar{x} \\
\pm s\end{array}$ & $\begin{array}{l}0.689 \\
0.623\end{array}$ & $\begin{array}{l}2.725 \\
1.382\end{array}$ & $\begin{array}{l}3.560 \\
1.444\end{array}$ & $\begin{array}{l}3.412 \\
0.989\end{array}$ & $\begin{array}{l}1.542 \\
0.35\end{array}$ & $\begin{array}{l}0.591 \\
0.364\end{array}$ & $\begin{array}{l}+) \\
+)\end{array}$ \\
\hline \multirow{2}{*}{$\begin{array}{l}\text { Turkeys } \\
\qquad(10 \text { animals) }\end{array}$} & 25 & $\begin{array}{r}\bar{x} \\
\pm s\end{array}$ & $\begin{array}{l}0.796 \\
0.607\end{array}$ & $\begin{array}{l}0.810 \\
0.386\end{array}$ & $\begin{array}{l}1.081 \\
0.319\end{array}$ & $\begin{array}{l}1.080 \\
0.372\end{array}$ & $\begin{array}{l}0.374 \\
0.209\end{array}$ & $\begin{array}{l}+) \\
+)\end{array}$ & $\begin{array}{l}+) \\
+)\end{array}$ \\
\hline & 50 & $\begin{array}{r}\bar{x} \\
\pm s\end{array}$ & $\begin{array}{l}1.015 \\
0.575\end{array}$ & $\begin{array}{l}1.763 \\
0.711\end{array}$ & $\begin{array}{l}2.993 \\
0.823\end{array}$ & $\begin{array}{l}2.432 \\
0.581\end{array}$ & $\begin{array}{l}1.288 \\
0.569\end{array}$ & $\begin{array}{l}0.436 \\
0.445\end{array}$ & $\begin{array}{l}+) \\
+)\end{array}$ \\
\hline \multirow{3}{*}{$\begin{array}{l}\text { Swine } \\
\qquad \text { (5 animals) }\end{array}$} & 10 & $\begin{array}{r}\bar{x} \\
\pm s\end{array}$ & $\begin{array}{l}0.339 \\
0.141\end{array}$ & $\begin{array}{l}0.781 \\
0.209\end{array}$ & $\begin{array}{l}1.029 \\
0.193\end{array}$ & $\begin{array}{l}0.713 \\
0.112\end{array}$ & $\begin{array}{l}0.266 \\
0.091\end{array}$ & $\begin{array}{l}+) \\
+)\end{array}$ & $\begin{array}{l}+) \\
+)\end{array}$ \\
\hline & 25 & $\begin{array}{r}\bar{x} \\
\pm s\end{array}$ & $\begin{array}{l}0.410 \\
0.227\end{array}$ & $\begin{array}{l}1.102 \\
0.461\end{array}$ & $\begin{array}{l}1.817 \\
0.704\end{array}$ & $\begin{array}{l}1.593 \\
0.340\end{array}$ & $\begin{array}{l}0.959 \\
0.223\end{array}$ & $\begin{array}{l}0.545 \\
0.163\end{array}$ & $\begin{array}{l}+) \\
+)\end{array}$ \\
\hline & 50 & $\begin{array}{r}\bar{x} \\
\pm s\end{array}$ & $\begin{array}{l}+) \\
+)\end{array}$ & $\begin{array}{l}1.425 \\
1.068\end{array}$ & $\begin{array}{l}4.311 \\
1.335\end{array}$ & $\begin{array}{l}4.569 \\
1.819\end{array}$ & $\begin{array}{l}2.039 \\
0.349\end{array}$ & $\begin{array}{l}1.411 \\
0.275\end{array}$ & $\begin{array}{l}0.363 \\
0.213\end{array}$ \\
\hline
\end{tabular}

Legend: $\quad+$ ) $=$ Values obtained, not useful for calculation.

$\bar{x} \pm s=$ mean arithmetic values and standard deviation. 
Fig. 1. Serum levels in chickens after single peroral administration of tiamulin.

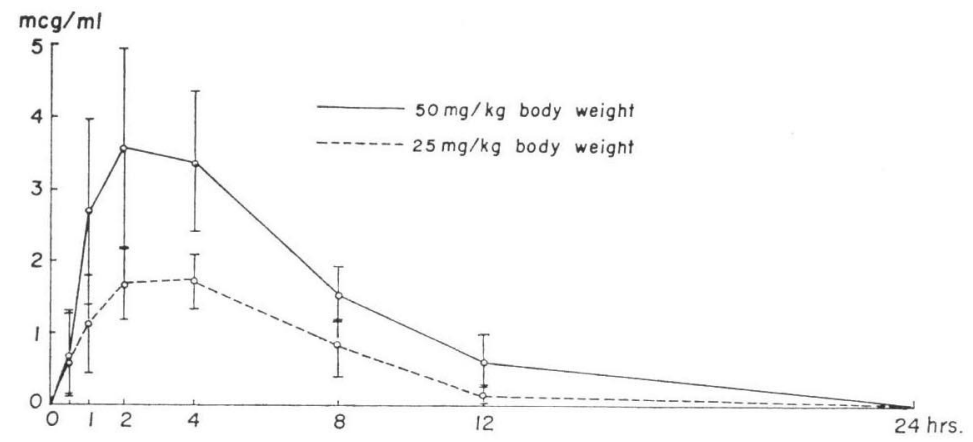

Fig. 2. Serum levels in turkeys after single peroral administrations of tiamulin.

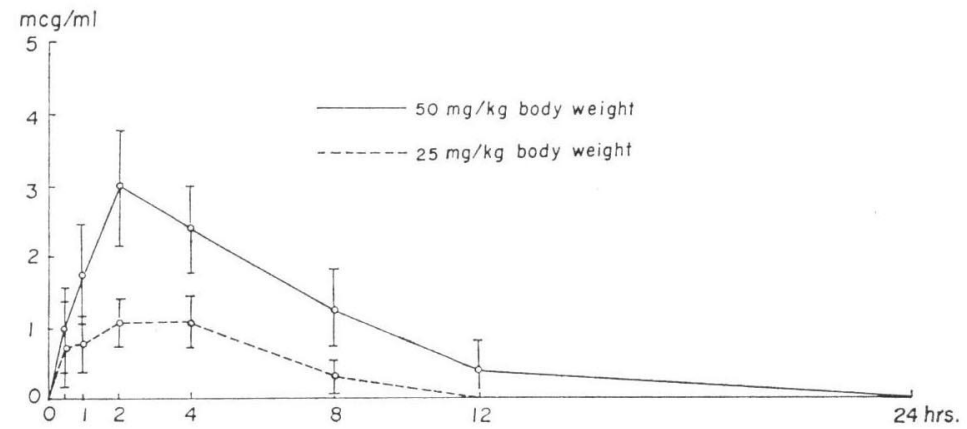

Fig. 3. Serum levels in swine after single peroral administration of tiamulin.

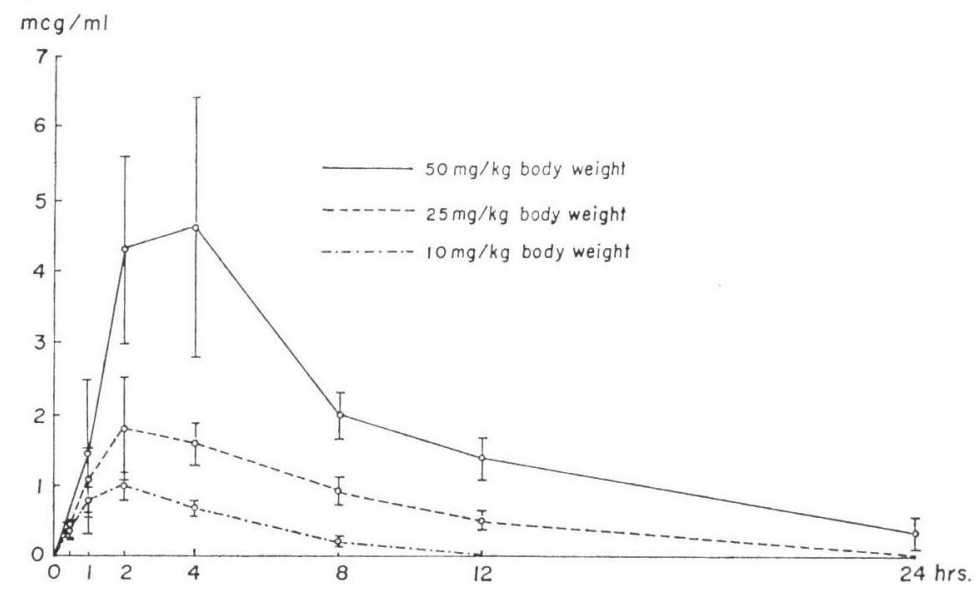

weight measurable values and values useful for calculation were only obtained up to 8 hours after start of treatment.

In swine, measurable serum levels could be found up to 24, 12 and 8 hours after administration of doses of 50,25 and $10 \mathrm{mg} / \mathrm{kg}$ body weight, respectively.

\section{References}

1) Knauseder, F. \& E. Brandl: Pleuromutilins. Fermentation, structure and biosynthesis. J. Antibiotics 29: $125 \sim 131,1976$ 
2) Egger, H. \& H. Reinshagen: New pleuromutilin derivatives with enhanced antimicrobial activity. I. Synthesis. J. Antibiotics 29: 915 922, 1976

3) Egger, H. \& H. Reinshagen: New pleuromutilin derivatives with enhanced antimicrobial activity. II. Structure-activity correlations. J. Antibiotics 29: 923 927, 1976

4) Drews, J.; A. Georgopoulos, G. Laber, E. Schütze \& J. Unger: Antimicrobial activities of 81.723 hfu, a new pleuromutilin derivative. Antimicr. Agents \& Chemoth. 7: 507 516, 1975

5) LABER, G.: Activity of various compounds against a pathogenic strain of Treponema hyodysenteriae. Zbl. Bakt. Hyg., I. Abt. Orig. A 236: 127 130, 1976

6) LABer, G. \& E. Schütze: In vitro und in vivo Wirksamkeit von Tiamulin gegen Leptospiren. Zbl. Bakt. Hyg., I. Abt. Orig. A (in press)

7) LABER, G. \& E. Schütze: In vivo efficacy of $81.723 \mathrm{hfu}$, a new pleuromutilin derivative against experimentally induced airsacculitis in chicks and turkey poults. Antimicr. Agents \& Chemoth. 7: 517 521,1975

8) Schuller, W.; G. Laber \& H. Walzl: Chemotherapeutische Untersuchungen mit 81.723 hfu (Tiamulin), einem neuen Pleuromutilin-Derivat, an der experimentellen Mykoplasma-Pneumonie des Schweines. Dtsch. Tierärztl. Wschr. (in press)

9) Baughn, C. O.; N. G. Anderson \& W. C. Alpaugh: The effect of 14-deoxy-14-[(2-diethylaminoethyl) mercaptoacetoxy] mutilin hydrogen fumarate (SQ 22.947, 81.723 hfu) in pigs experimentally infected with swine dysentery. 14th Intersci. Conf. on Antimicr. Agents \& Chemoth., San Francisco, paper 204, Sept. 12, 1974

10) Glawischnig, E. \& K. Steininger: Therapy of enzootic pneumonia in swine with tiamutilin ( $81.723 \mathrm{hfu})$ under field conditions. Proc. Int. Pig. Vet. Soc., PP2, Ames Iowa, 1976

11) Stipkovits, L.; G. LAber \& E. Schütze: Prophylactical and therapeutical efficacy of tiamulin in mycoplasmosis of chickens and turkeys. Poultry Sci. 56: 1209 1215, 1977

12) Stipkovits, L.; G. Laber \& E. Schütze: Tiamulin, a new antibiotic for controlling of enzootic pneumonia in swine. Pig International (in press)

13) Linder, A.: Statistische Methoden. Birkhäuser Verlag Basel, 1960 